\title{
ANALISIS PENINGKATAN KOMPETENSI PEDAGOGIK GURU DALAM PEMBELAJARAN EKONOMI DI SMA NEGERI 1 SUTOJAYAN
}

\author{
Naning Eko Noviana, IKIP Widya Darma \\ naningekonoviana@ikipwidyadarma.ac.id
}

\begin{abstract}
ABSTRAK
Guru merupakan ujung tombak bagi keberhasilan pengajaran, pendidikan, pembimbingan, dan pelatihan bagi siswanya. bahwasanya untuk mencapai keberhasilan dalam pengajaran, guru tentu harus memiliki kompetensi di dalam bidangnya. Kompetensi guru yang paling utama ada pada kompetensi pedagogik. Tujuan dari penelitian ini adalah untuk menganalisis pentingnya pemahaman tentang kompetensi pedagogik dalam meningkatkan pembelajaran guru ekonomi di SMA Negeri 1 Sutojayan. Metode dalam penelitian ini adalah metode penelitian dengan pendekatan studi kasus. Teknik analisis menggunakan teknik triangulasi waktu dan sumber. Hasil penelitian menunjukkan bahwa guru telah mampu memahami kompetensi pedagogik sesuai dengan Undang-Undang. Kata Kunci: Guru, Kompetensi Pedagogik, Pembelajaran Ekonomi.
\end{abstract}

\begin{abstract}
Teachers are at the spearhead of successful teaching, education, mentoring, and training for their students. That success in teaching, teachers must have competence in the field. The main important teacher competence is pedagogic competence. The purpose of this research is to know the importance of understanding about pedagogic competence in improving learning. The method in this research is qualitative method with case study approach. Techniques of collecting research data through observation, interviews, and documentation. The results showed that teachers have been able to understand pedagogic competence in accordance with Law.
\end{abstract}

Keywords: Teacher, Pegagogic Competence, Economics Teaching.

\section{PENDAHULUAN}

Guru selalu menjadi pembicaraan yang menarik bagi para siswanya. Siswa kebanyakan akan mengidolakan guru yang menurut mereka pantas dan tepat sesuai dengan porsi mereka. Ada seorang guru yang memiliki pembawaan khas dan unik dalam cara mereka mengajar. Mereka melakukan hal demikian agar apa yang disampaikan dalam proses KBM berjalan lancar dan mampu dipahami oleh siswanya. Namun di sisi lain, seorang guru juga seharusnya mampu secara utuh memahami pentingnya kompetensi guru.

Menurut Undang-Undang Nomor 14 tahun 2005 tentang standar nasional pendidikan menyebutkan bahwa guru yang berkompeten memiliki kualifikasi 
pendidikan minimum sarjana, menguasai empat kompetensi, bersertifikat pendidik, sehat jasmani dan rohani, serta mampu mewujudkan tujuan pendidikan nasional.

Berdasarkan undang-undang di atas kompetensi guru merupakan kemampuan yang ditunjukkan melalui tingkat pendidikan dan penguasaan terhadap pengetahuan seperti yang diungkapkan oleh Ahmad(2009) menyatakan bahwa kompetensi adalah suatu kemampuan menguasai dan menerapkan pengetahuan, keterampilan/ keahlian dan sikap kerja tertentu di tempat kerja sesuai dengan kinerja yang dipersyaratkan.

Timbal balik yang diperoleh guru dari semua ini adalah pembelajaran yang semakin menarik dan siswa pun mampu menyatu dengan guru masingmasing. Namun tidak semua kompetensi guru mampu dijalankan terlebih dalam kompetensi pedagogik. Kompetensi pedagogik adalah kompetensi pertama yang harus dikuasai oleh seorang guru. Kebanyakan dalam proses KBM masih ada guru yang belum mampu menerapkan kompetensi pedagogik dengan baik. Seperti yang diungkapkan oleh Mulyasa (2006) dalam kasus kegagalan belajar siswa, ternyata guru belum sepenuhnya memahami bagaimana menjalankan kompetensi pedagogik dengan baik, sehingga menjadi faktor kesulitan dan ketidaksemangatan peserta didik dalam belajar.

Mujib (2012) mendefinisikan kompetensi pada dasarnya merupakan gambaran tentang apa yang sebaiknya dapat dilakukan (be able to do) seseorang dalam suatu pekerjaan, yang berupa kegiatan, perilaku, dan hasil yang sebaiknya dapat ditampilkan. Berbeda pendapat dengan Mujib, menurut Mulyasa (2013) menyatakan bahwa kompetensi guru merupakan perpaduan antara kemampuan personal, keilmuan, teknologi, sosial dan spiritual yang secara kaffah membentuk kompetensi standar profesi guru, yang mencakup penguasaan materi, pemahaman terhadap peserta didik, pembelajaran yang mendidik, pengembangan pribadi dan profesionalisme.

Payong (2011) menyatakan bahwa pengertian pedagogis adalah segala bentuk usaha yang dilakukan oleh pendidik untuk membimbing anak muda menjadi manusia yang dewasa dan matang.

Kompetensi pedagogik pada hakikatnya berpusat pada guru sebagai tenaga pengajar yang memiliki kemampuan dalam mengatur jalannya sebuah pembelajaran. Alma (2009) menyatakan bahwa kompetensi pedagogik adalah kemampuan mengelola pembelajaran. Ini mencakup konsep kesiapan mengajar yang ditunjukkan oleh penguasaan pengetahuan dan keterampilan mengajar.

Peraturan Menteri Pendidikan Nasional No. 16 tahun 2007 tentang Standar Kualifikasi dan Kompetensi Guru telah menggarisbawahi 10 kompetensi inti yang harus dimiliki oleh guru yang terkait dengan standar kompetensi pedagogis. Kesepuluh kompetensi inti itu adalah sebagai berikut: a) Menguasai karakteristik peserta didik dari aspek fisik, moral, kultural, emosional, dan intelektual; b) Menguasai teori-teori belajar dan prinsip-prinsip pembelajaran yang mendidik; c) Mengembangkan kurikulum yang terkait dengan mata pelajaran atau bidang pengembangan yang diampu; d) Menyelenggarakan pembelajaran yang mendidik; e) Memanfaatkan teknologi informasi dan komunikasi untuk kepentingan pembelajaran; f) Memfasilitasi pengembangan potensi peserta didik untuk mengaktualisasikan berbagai potensi yang dimilikinya; g) Berkomunikasi secara efektif, empatik, dan santun 
dengan peserta didik; h) Menyelenggarakan penilaian dan evaluasi proses dan hasil belajar; i) Memanfaatkan hasil penilaian dan evaluasi untuk kepentingan pembelajaran; j) Melakukan tindakan reflektif untuk peningkatan kualitas pembelajaran.

Berdasarkan wawancara awal yang dilakukan peneliti di SMA Negeri 1 Sutojayan menyatakan bahwa guru mampu menyatu dengan para siswanya dan memiliki keakraban yang solid jika siswa memiliki permasalahan baik secara akademis maupun non akademis. Guru juga terlihat bercanda ria disela-sela proses KBM yang sedang berjalan sehingga kelas memiliki suasana menjadi lebih hidup. Namun di sisi lain beberapa guru khususnya guru ekonomi tampaknya memiliki kesulitan membuat model dan metode pembelajaran yang mampu menarik siswa untuk lebih giat memperhatikan pelajaran. Di sisi lain menurut mereka, ke sekolah hanya untuk rutinitas kerja saja. Maka berdasarkan hasil wawancara awal tersebut tujuan dari penelitian ini adalah untuk mengetahui pentingnya pemahaman guru mengenai kompetensi pedagogik guru ekonomi di SMAN 1 Sutojayan.

\section{METODE PENELITIAN}

Dalam penelitian ini, metode penelitian yang digunakan adalah penelitian kualitatif dengan pendekatan studi kasus. Peneliti ingin melakukan proses analisis secara mendalam terhadap objek penelitian. Tahapan-tahapan dalam penelitian yang dilakukan di SMA Negeri 1 Sutojayan yang pertama adalah melakukan tahap observasi awal guna mengetahui gambaran secara umum di SMAN 1 Sutojayan, tahap selanjutnya adalah tahap reduksi yang mana di dalam tahap ini peneliti memilih data dan menentukan fokus permasalahan yang ditemukan, tahap selanjutnya adalah tahap seleksi diartikan sebagai tahap yang menguraikan fokus permasalahan mengenai pentingnya pemahaman guru tentang kompetensi pedagogik guru ekonomi di SMAN 1 Sutojayan, kemudian analsis data, melakukan triangulasi dan menyimpulkan hasil penelitian.

Uji teknik keabsahan data menggunakan teknik triangulasi. Teknik ini bertujuan untuk memeriksa keabsahan data menggunakan berbagai sumber dengan berbagai cara dan waktu. Sehingga data yang dihasilkan teruji keabsahannya. Uji keabsahan data menggunakan triangulasi waktu dan teknik.

Penentuan sampel pada penelitian yang dilakukan di SMA 1 Sutojayan Kabupaten Blitar masih bersifat sementara dan akan berkembangan setelah peneliti terjun ke lapangan. Sampel yang dipilih sesuai dalam penelitian ini adalah purposive sampling yaitu sampel sumber data bertujuan untuk mengetahui secara mendalam bagaimana pemahaman guru mengenai pentingnya kompetensi pedagogik kepada informan yang dianggap menguasai topik yang dibahas. Sampel yang dipilih dalam penelitian ini adalah

1. Suwondo S.Pd guru ekonomi sekaligus ketua MGMP guru ekonomi Kabupaten Blitar.

2. Nur Wahyuni, S.Pd guru ekonomi SMA Negeri 1 Sutojayan

3. Meisaroh siswa SMA Negeri 1 Sutojayan kelas XII IPS

Teknik pengumpulan data menggunakan observasi dilakukan peneliti dengan melakukan pengamatan secara langsung ke lapangan mengenai 
keadaan guru dan aktifitas guru sehari-hari. Kemudian wawancara merupakan satu-satunya metode yang efektif dalam penelitian kualitatif. Wawancara yang dilakukan dalam penelitian ini adalah wawancara tidak stuktur, dan dokumentasi dilakukan peneliti dengan cara memilih arsip-arsip yang berkaitan dengan objek penelitian.

\section{HASIL DAN PEMBAHASAN}

Peraturan Menteri Pendidikan Nasional No. 16 tahun 2007 tentang Standar Kualifikasi dan Kompetensi Guru telah menggarisbawahi 10 kompetensi inti diantaranya meliputi; 1) Menguasai karakteristik peserta didik dari aspek fisik, moral, kultural, emosional, dan intelektual; 2) Menguasai teori-teori belajar dan prinsip-prinsip pembelajaran yang mendidik; 3) Mengembangkan kurikulum yang terkait dengan mata pelajaran atau bidang pengembangan yang diampu; 4) Menyelenggarakan pembelajaran yang mendidik; 5) Memanfaatkan teknologi informasi dan komunikasi untuk kepentingan pembelajaran; 6) Memfasilitasi pengembangan potensi peserta didik untuk mengaktualisasikan berbagai potensi yang dimilikinya; 7) Berkomunikasi secara efektif, empatik, dan santun dengan peserta didik; 8 )Menyelenggarakan penilaian dan evaluasi proses dan hasil belajar; 9) Memanfaatkan hasil penilaian dan evaluasi untuk kepentingan pembelajaran; 10) Melakukan tindakan reflektif untuk peningkatan kualitas pembelajaran.

\section{Pemahaman tentang pentingnya kompetensi pedagogik di SMA 1 Sutojayan}

a. Menguasai karakteristik peserta didik dari aspek fisik, moral, kultural, emosional, dan intelektual.

Menurut Kementerian Pendidikan Nasional tentang pedoman pelaksanaa penilaian kinerja guru (PK Guru) pada penguasaan karakteristik peserta didik dari aspek fisik, moral, kultural, emosional, dan intelektual menyebutkan bahwa: 1) Guru dapat mengidentifikasikan kharakteristik belajar setiap peserta didik di kelasnya; 2) Guru memastikan bahwa semua peserta didik mendapatkan kesempatan yang sama untuk berpartisipasi aktif dalam kegiatan pembelajaran; 3) Guru dapat mengukur kelas untuk memberikan kesempatan belajar yang sama pada semua peserta didik dengan kelalaian fisik dan kemampuan belajar yang berbeda; 4) Guru mencoba mengetahui penyebab penyimpangan perilaku peseta didik untuk mencegah agar perilaku tidak merugikan peserta didik lainya; 5) Guru membantu mengembangkan potensi dan mengatasi kekurangan peserta didik; 6) Guru memperlihatkan peserta didik dengan kelemahan fisik tertentu agar dapat mengikuti aktifitas pembelajaran, sehingga peserta didik tersebut tidak termarjinalkan (tersisih, diolok-olok, minder)

Berdasarkan hasil wawancara kepada Bapak Suwondo selaku guru ekonomi menunjukkan hasil yang sesui dengan apa yang tertera dalam Peraturan Kementerian Pendidikan Nasional tentang pedoman pelaksanaa penilaian kinerja guru (PK Guru). Pada penguasaan karakteristik peserta didik dari aspek fisik, moral, kultural, emosional, dan intelektual yang dilaksanakan pada tanggal 24 Mei 2018 menyatakan bahwa: 
"Saya sebetulnya sudah mengembangkan minat dan bakat siswa dengan cara berbincang dengan mereka, juga menerapkan pos-tes saat pembelajaran dan kerap sekali membantu siswa untuk menemukan potensi apayang ada pada diri siswa".

Hasil wawancara ke dua dilakukan dengan nara sumber yang sama yaitu Bapak Suwondo pada tanggal yang berbeda yaitu pada tanggal 19 Juli 2018 menyatakan bahwa:

"Saya sendiri sebetulnya suka bercanda dengan para siswa disela-sela pembelajaran agar pembelajaran yang saya lakukan tidak terlihat kaku"

\section{b. Menguasai teori-teori belajar dan prinsip-prinsip pembelajaran yang mendidik}

Menurut Kementerian Pendidikan Nasional tentang pedoman pelaksanaa penilaian kinerja guru (PK Guru) pada penguasaan teori-teori belajar dan prinsip-prinsip pembelajaran yang mendidik menyebutkan bahwa: 1) Guru memberi kesempatan kepada peserta didik untuk menguasai materi pembelajaran sesuai usia dan kemampuan belajarnya melalui pengaturan proses pembelajaran dan aktifitas yang bervariasi; 2) Guru selalu memastikan tingkat pemahaman peserta didik terhadap materi pembelajaran tertentu dan menyesuaikan aktifitas pembelajaran berikutnya berdasarkan tingkat pemahaman tersebut; 3) Guru dapat menjelaskan alasan pelaksanaan kegiatan/ aktifitas yang dilakukannya, baik yang sesuai maupun yang berbeda dengan rencana, terkait keberhasilan pembelajaran; 4) Guru menggunakan berbagai teknik untuk memotivasi kemauan belajar peserta didik; 5) Guru merencanakan kegiatan pembelajaran yang saling terkait satu sama lain, dengan memperlihatkan tujuan pembelajaran maupun proses belajar peserta didik; 6) Guru memperhatikan respon peserta didik yang belum/kurang memahami materi pembelajaran yang diajarkan dan menggunakannya untuk memperbaiki rancangan pembelajaran berikutnya

Berdasarkan hasil wawancara kepada Bapak Suwondo selaku guru ekonomi menunjukkan hasil yang sesui dengan apa yang tertera dalam Peraturan Kementerian Pendidikan Nasional tentang pedoman pelaksanaa penilaian kinerja guru (PK Guru). Pada penguasaan teori-teori belajar dan prinsip-prinsip pembelajaran yang mendidik yang dilaksanakan pada tanggal 24 Mei 2018 menyatakan bahwa:

"saya sering menyuruh siswa menyelesaikan masalah dengan memberi studi kasus, lalu menyampaikan tujuan pembelajaran yang akan dicapai dan membuat metode pembelajaran yang sesuai dengan kompetensi dasar yang akan dibahas".

Hasil wawancara ke dua dilakukan dengan nara sumber yang berbeda yaitu Meisaroh sebagai siswa SMAN 1 Sutojayan pada tanggal 19 Juli 2018 menyatakan bahwa: 
"Pak wanda biasanya sering memberi kasus-kasus yang dikerjakan dengan berkelompok"

\section{c. Mengembangkan kurikulum yang terkait dengan mata pelajaran atau bidang pengembangan yang diampu}

Menurut Kementerian Pendidikan Nasional tentang pedoman pelaksana penilaian kinerja guru (PK Guru) pengembangan kurikulum yang terkait dengan mata pelajaran atau bidang pengembangan yang diampu menyebutkan bahwa: 1) Guru dapat menyusun silabus yang sesuai dengan kurikulum; 2) Guru merancang rencana pembelajaran yang sesuai dengan silabus untuk membahas materi ajar tertentu agar peserta didik dapat mencapai kompetensi dasar yang ditetapkan; 3) Guru mengikuti urutan materi pembelajaran dengan memperhatikan tujuan pembelajaran; 4) Guru memilih materi pembelajaran yang sesuai dengan tujuan pembelajaran, tepat dan mutakhir, sesuai dengan usia dan tingkat kemampuan belajar peserta didik, dapat dilaksanakan dikelas, dan sesuai dengan konteks kehidupan sehari-hari peserta didik.

Berdasarkan hasil wawancara kepada Bapak Suwondo selaku guru ekonomi menunjukkan hasil yang sesui dengan apa yang tertera dalam Peraturan Kementerian Pendidikan Nasional tentang pedoman pelaksanaa penilaian kinerja guru (PK Guru). Pada pengembangan kurikulum yang terkait dengan mata pelajaran atau bidang pengembangan yang diampu, yang dilaksanakan pada tanggal 26 Mei 2018 menyatakan bahwa:

"saya telah membuat metode dan model pembelajaran yang sesuai dengan kompetensi dasar dan membuat rencana pelaksanaan pembelajaran (RPP) secara mandiri karena saya juga merangkap sebagai ketua MGMP guru ekonomi Kabupaten Blitar maka saya harus menjadi contoh yang baik"

Hasil wawancara ke dua dilakukan dengan nara sumber yang sama yaitu Bapak Suwondo pada tanggal yang berbeda yaitu pada tanggal 19 Juli 2018 menyatakan bahwa:

"ya saya membuat RPP khusus mata pelajaran saya sendiri dan membuat modelpembelajaran yang bermacam-macam "

\section{d. Menyelenggarakan pembelajaran yang mendidik}

Menurut Kementerian Pendidikan Nasional tentang pedoman pelaksanaa penilaian kinerja guru (PK Guru) pada penyelenggaraan pembelajaran yang mendidikmenyebutkan bahwa: 1) Guru melaksanakan aktivitas pembelajaran sesuai dengan rancangan yang telah disusun secara lengkap dan pelaksanaan aktifitas tersebut mengindikasikan bahwa guru mengerti tentang tujunnnya; 2) Guru melaksanakan aktifitas pembelajarannya yang bertujuan untuk membantu proses belajar peserta didik, bukan menguji sehingga membuat peserta didik merasa tertekan; 3) Guru mengkomunikasikan informasi baru (misalnya materi tambahan) sesuai dengan usia dan tingkat kemampuan belajar peserta didik; 4) Guru menyikapi kesalahan yang dilakukan peserta didik sebagai tahapan proses pembelajaran, bukan semata-mata kesalahan yang harus dikoreksi; 5) 
Guru melaksanakan pembelajaran sesuai dengan kurikulum dan mengkaitkannya dengan kontek kehidupan sehari-hari

Berdasarkan hasil wawancara kepada Bapak Suwondo selaku guru ekonomi di SMA Negeri 1 Sutojayan menunjukkan hasil yang sesui dengan apa yang tertera dalam Peraturan Kementerian Pendidikan Nasional tentang pedoman pelaksanaa penilaian kinerja guru (PK Guru). Pada penyelenggaraan pembelajaran yang mendidik, yang dilaksanakan pada tanggal 26 Mei 2018 menyatakan bahwa:

" saya membuat model dan metode pembelajaran yang berganti-ganti lalu melaksanakan pembelajaran sesuai dengan rencana pelaksanaan pembelajaran (RPP)".

Hasil wawancara ke dua dilakukan dengan nara sumber yang berbeda yaitu Ibu Nur Wahyuni selaku guru ekonomi pada tanggal 21 Juli 2018 menyatakan bahwa:

"kalau disini memang setiap guru harus mampu mengajar sesuai dengan tujuan yang ada di materi yang akan disampaikan sehingga siswanya menjadi siap dalam belajar"

\section{e. Memanfaatkan teknologi informasi dan komunikasi untuk kepentingan pembelajaran.}

Menurut Payong dalam Wardani (2017) menyatakan bahwa guru harus bisa memanfaatkan teknologi komputer untuk memudahkan pembelajaran atau mengemas pesan-pesan pembelajaran secara menarik, sehingga dapat menggunggah minat dan motivasi belajar siswa.

Berdasarkan hasil wawancara kepada Bapak Suwondo selaku guru ekonomi SMA Negeri 1 Sutojayan menunjukkan hasil yang sesui dengan apa yang tertera dalam teknologi informasi dan komunikasi untuk kepentingan pembelajaran yang dilaksanakan pada tanggal 26 Mei 2018 menyatakan bahwa:

"saya sering berinteraksi dengan siswa baik disekolah maupun tidak dan menggunakan media sosial seperti grup whatshapp ketika saya memberi tugas dan berhalangan masuk"

Hasil wawancara ke dua dilakukan dengan nara sumber yang berbeda yaitu Meisaroh sebagai siswa SMAN 1 Sutojayan pada tanggal 19 Juli 2018 menyatakan bahwa:

"saya punya grup whatsapp yang gurunya pak wanda, karena kalau waktu beliau tidak masuk biasanya whatsapp di grup"

\section{f. Memfasilitasi pengembangan potensi peserta didik untuk mengaktualisasikan berbagai potensi yang dimilikinya.}

Menurut Kementerian Pendidikan Nasional tentang pedoman pelaksanaa penilaian kinerja guru (PK Guru) pada pengembangan potensi peserta didik 
untuk mengaktualisasikan berbagai potensi yang dimilikinyamenyebutkan bahwa: 1) Guru menganalisis hasil belajar berdasarkan segala bentuk hasil penilaian terhadap setiap peserta didik untuk mengetahui tingkat kemajuan masing-masing; 2) Guru merancang dan melaksanakan aktifitas pembelajaran yang mendorong peserta didik untuk belajar sesuai dengan kecakapan dan pola belajar masing-masing; 3) Guru merancang dan melaksanakan aktifitas pembelajaran untuk memunculkan daya kreatifitas dan kemampuan berfikir kritis peserta didik; 4) Guru secara aktif membantu peserta didik dalam proses pembelajaran dengan memberikan perhatian kepada peserta didik; 5) Guru mengidentifikasi dengan benar-benar tentang bakat, minat, potensi, dan kesulitas belajar masing-masing peserta didik

Berdasarkan hasil wawancara kepada Bapak Suwondo selaku guru ekonomi di SMA Negeri 1 Sutojayan menunjukkan hasil yang sesuai dengan apa yang tertera dalam Peraturan Kementerian Pendidikan Nasional tentang pelaksana penilaian kinerja guru (PK Guru). Pada pengembangan potensi peserta didik untuk mengaktualisasikan berbagai potensi yang dimilikinya pada tanggal 29 Mei 2018 menyatakan bahwa:

" hasil belajar siswa selalu saya evaluasi agar saya tahu bagaimana harus meningkatkan prestasi anak-anak dan juga meningkatkan potensi mereka jika dalam mata pelajaran tertentu mereka memiliki nilai yang jelek"

Hasil wawancara ke dua dilakukan dengan nara sumber yang berbeda yaitu Ibu Nur Wahyuni selaku guru ekonomi pada tanggal 21 Juli 2018 menyatakan bahwa:

“di sini selalu dilakukan tahap evaluasi agar tahu kemajuan nilai-nilai anak anak"

\section{g. Berkomunikasi secara efektif, empatik, dan santun dengan peserta didik.}

Menurut Kementerian Pendidikan Nasional Direktorat Jenderal Peningkatan Mutu Pendidik dan Tenaga Kependidikan 2010 menyatakan bahwa guru harus mampu berkomunikasi secara efektif, empatik, dan santun dengan peserta didik dan bersikap antusias dan positif. Guru harus mampu memberikan respon yang lengkap dan relevan pada komentar dan pertanyaan peserta didik.

Berdasarkan hasil wawancara kepada Bapak Suwondo selaku guru ekonomi SMA Negeri 1 Sutojayan menunjukkan hasil yang sesui dengan apa yang tertera dalam Peraturan Kementerian Pendidikan Nasional tentang Peningkatan Mutu Pendidik dan Tenaga Kependidikan 2010, pada tanggal 30 Mei menyatakan bahwa:

“ Saya sering berdiskusi dengan siswa dan memberi arahan pada siswa jika mengalami permasalahan baik secara akademis maupun nonakademis". 
Hasil wawancara ke dua dilakukan dengan nara sumber yang berbeda yaitu Meisaroh sebagai siswa SMAN 1 Sutojayan pada tanggal 19 Juli 2018 menyatakan bahwa:

"sering kalau berdiskusi langsung dan kalau dikelas biasanya memberi nasehat pada semua anak-anak"

\section{h. Menyelenggarakan penilaian dan evaluasi proses dan hasil belajar}

Menurut Menurut Kementerian Pendidikan Nasional tentang pedoman pelaksanaa penilaian kinerja guru (PK Guru) pada penyelenggaraan penilaian dan evaluasi proses dan hasil belajar menyebutkan bahwa: 1) Guru menyusun alat penilaian yang sesuai dengan tujuan pembelajaran untuk mencapai kompetensi tertentu seperti yang tertulis dalam RPP; 2) Guru melaksanakan penilaian dengan berbagai teknik dan jenis penilaian; 3) Guru menganalisis hasil penilaian untuk mengidentifikasi topik/ kompetensi dasar yang sulit sehingga diketahui kekuatan dan kelemahan masing-masing peserta didik untuk keperluan remidial dan pengayaan.

Berdasarkan hasil wawancara kepada Bapak Suwondo selaku guru ekonomi menunjukkan hasil yang sesuai dengan apa yang tertera dalam Peraturan Kementerian Pendidikan Nasional tentang pedoman pelaksanaa penilaian kinerja guru (PK Guru). Pada penyelenggaraan penilaian dan evaluasi proses dan hasil belajar yang dilakukan pada tanggal 30 Mei 2018 menyatakan bahwa:

“ Saya sering melakukan kesepakatan dengan siswa terkait dengan model pembelajaran pada materi selanjutnya, menampung keinginan siswa demi terciptanya pendidikan yang baik, mengevaluasi hasil belajar siswa, dan menggunakan jenis penilaian macam-macam untuk siswa baik nilai individu maupun kelompok".

Hasil wawancara ke dua dilakukan dengan nara sumber yang berbeda yaitu Meisaroh sebagai siswa SMAN 1 Sutojayan pada tanggal 19 Juli 2018 menyatakan bahwa:

"kalau pak wanda biasnaya memberi nilai saya dengan pas-pasan atau biasanya dalam satu kelas sama".

\section{Pembahasan Tentang Pentingnya kompetensi pedagogik di SMA 1 Sutojayan}

Setelah dilakukan hasil wawancara diperoleh data yang sesuai dengan hasil teknik triangulasi sumber dan triangulasi waktu. Diketahui hasil wawancara menunjukkan data yang valid karena dilakukan pada bulan, hari, dan tanggal yang berbeda menunjukkan jawaban yang sama. disisi lain triangulasi data dilakukan dengan triangulasi sumber diantaranya ada tiga sumber yaitu Bapak Suwondo S.Pd selaku guru ekonomi sekaligus ketua MGMP guru ekonomi Kabupaten Blitar, Nur Wahyuni, S.Pd selaku guru ekonomi, dan Meisaroh siswa SMAN 1 Sutojayan yang mana menunjukkan 
hasil yang serupa dengan informan pertama. Dalam penelitian ini juga didukung oleh penelitian terdahulu diantaranya:

Imam Suraji (2012) meneliti tentang urgensi kompetensi guru menyimpulkan bahwa kompetensi merupakan salah satu syarat mutlak yang harus dimiliki guru. Dengan kompetensi, seseorang guru akan mampu melaksanakan tugasnya sebagai pendidik dan agen pembelajar secara profesional.

Tabi'in (2016) meneliti tentang kompetensi guru dalam meningkatkan motivasi belajar pada MTsN Pekan Heran Indragiri Hulu menyimpulkan bahwa motivasi belajar siswa MTsN Pekan Heran cukup baik karena dipengaruhi dengan adanya kegiatan yang diadakan sekolah untuk menumbuhkan minat belajar.

Annisa. 2017. meneliti tentang pentingnya kompetensi guru dalam kegiatan pembelajaran di SD (Sekolah Dasar) menyimpulkan bahwa untuk mewujudkan pembelajaran yang menyenangkan tersebut harus ada dukungan dari pihak guru yang mana guru harus memiliki empat kompetensi yaitu yang pertama kompetensi pedagogik, profesional, sosial, dan kepribadian.

Berdasarkan penelitian terdahulu diperoleh sebuah pemaparan yang sama dengan hasil penelitian bahwa guru sudah memahami pentingnya kompetensi pedagogik dalam meningkatkan pembelajaran ekonomi di SMA Negeri 1 Sutojayan yang sesuai dengan Peraturan Menteri Pendidikan Nasional No. 16 tahun 2007 tentang Standar Kualifikasi dan Kompetensi Guru telah menggarisbawahi 10 kompetensi inti yang harus dimiliki oleh guru yang terkait dengan standar kompetensi pedagogis. Kesepuluh kompetensi inti itu adalah sebagai berikut: a) Menguasai karakteristik peserta didik dari aspek fisik, moral, kultural, emosional, dan intelektual; b) Menguasai teori-teori belajar dan prinsip-prinsip pembelajaran yang mendidik; c) Mengembangkan kurikulum yang terkait dengan mata pelajaran atau bidang pengembangan yang diampu; d) Menyelenggarakan pembelajaran yang mendidik; e) Memanfaatkan teknologi informasi dan komunikasi untuk kepentingan pembelajaran; f) Memfasilitasi pengembangan potensi peserta didik untuk mengaktualisasikan berbagai potensi yang dimilikinya; g) Berkomunikasi secara efektif, empatik, dan santun dengan peserta didik; h) Menyelenggarakan penilaian dan evaluasi proses dan hasil belajar; i) Memanfaatkan hasil penilaian dan evaluasi untuk kepentingan pembelajaran; j) Melakukan tindakan reflektif untuk peningkatan kualitas pembelajaran.

\section{SIMPULAN}

Berdasarkan hasil penelitian dapat disimpulkan bahwa guru telah memahami pentingnya kompetensi pedagogik untuk peningkatan pembelajaran di SMA 1 Sutojayan. Beberapa poin penting yang telah dilaksanakan guru dalam berkompetensi khususnya kompetensi pedagogik di antaranya: senantiasa mengembangkan potensi dan minat siswa; mengembangkan potensi dan minat siswa, memberi post-test dan pre-test pada saat pembelajaran; membantu siswa untuk menemukan kelemahan dan kelebihan yang ada pada diri siswa; menyuruh siswa menyelesaikan masalah dengan memberi studi kasus; menyampaikan tujuan pembelajaran yang akan dicapai; membuat 
metode dan model pembelajaran yang sesuai dengan kompetensi dasar; membuat metode dan model pembelajaran yang sesuai dengan kompetensi dasar; membuat rencana pelaksanaan pembelajaran (RPP) secara mandiri; menggunakan literatur ekonomi yang bersifat offline (berbentuk data tanpa menggunakan jaringan internet) maupun online; mengadakan adanya ekstrakulikuler di luar jam mengajar; memberi waktu di luar jam kelas untuk berdiskusi dengan siswa; memberi arahan pada siswa jika mengalami permasalahan baik secara akademis maupun non-akademis; mengevaluasi hasil belajar siswa; menggunakan berbagai jenis penilaian untuk siswa baik nilai individu maupun kelompok; dan memberi kesempatan siswa untuk bertanya mengenai materi pelajaran yang dibahas.

\section{DAFTAR RUJUKAN}

Ahmad. 2009. Integrated Human Resource Development Berdasarkan Pendekatan CB-HRM, TB-HRM, CBT, dan CPD. Jakarta: PT. Grasindo

Alma, Buchari. 2009. Guru Profesional (Menguasai Metode dan Terampil Mengajar). Bandung: Alfabeta

Annisa, Awalina, N. 2017. Pentingnya Kompetensi Guru Dalam Kegiatan Pembelajaran Di SD. (Jurnal Online). Fakultas Ilmu Pendidikan Universitas Negeri Yogyakarta.

As'Adut Tabi'in. 2016. Kompetensi Guru dalam Meningkatkan Motivasi Belajar pada MTsn Pekan Heran Indragiri Hulu. Dalam jurnal AlThariqah (Vo. 1, No. 2, Desember 2016) (online tanggal 28 juli 2018)

Horby, A.S. 1989. Oxford Advanced Learner's Dictionary of Current English (1989). Fourth Edition. Oxford: Oxford University Press

Kementerian Pendidikan Nasional. Direktorat Jenderal Peningkatan Mutu Pendidik dan Tenaga Kependidikan. 2010. Pedoman Pelaksanaan Penilaian Kinerja Guru (PK Guru). Jakarta: bermutuprofesi.org

Mujib , Fathul. 2012. Super Power In Educating. Jogyakarta: DIVA Press

Mulyasa. 2006. Kurikulum Yang Disempurnakan. Bandung: PT Remaja Rosdakarya

Mulyasa. 2013. Standar Kompetensi dan Sertifikasi Guru. Bandung: Remaja Rosdakarya.

Payong, Marselus 2011. Sertifikasi Profesi Guru Konsep Dasar, Problematika, Dan Implementasinya. Jakarta: PT Indeks 
Peraturan Menteri Pendidikan Nasional No. 16 tahun 2007 tentang Standar Kualifikasi dan Kompetensi Guru

Suraji, Imam. 2012. Urgensi Kompetensi Guru. Dalam jurnal forum tarbiyah (Vol. 10. No.2, Desember 2012) (online tanggal 31 Juli 2018).

Wardani, Winda Kusuma. 2017. Analisis Kompetensi Pedagogik Guru Dalam Proses Pembelajaran di SD Muhammadiyah 16 Surakarta. Skripsi tidak diterbitkan, Fakultas Keguruan dan Ilmu Pendidikan Universitas Muhammadiyah Surakarta. 